\title{
A Prudential trade-off? Leakages and Interactions with Monetary Policy*
}

\author{
Baptiste Meunier ${ }^{1 \dagger}$, Justine Pedrono ${ }^{1 \ddagger}$ \\ January 2021, WP \#805
}

\begin{abstract}
While monetary and prudential policies are generally analysed separately, this paper focuses on how the two interact. Taking an international perspective, we show that monetary policy in a centre economy (Euro Area) spill over its borders through bank lending - therefore inducing volatility in cross-border lending flows. Investigating a sample of 30 advanced and emerging economies, we find evidence that prudential policy in the receiving-country interact with monetary policy so that a tighter prudential stance in the recipient-country mitigates the volatility of banking flows induced by monetary policy abroad. But we also show that a tighter prudential stance - interactions apart implies a higher growth of cross-border lending. Taken together, these results might suggest a trade-off: while a tighter prudential stance reduces the volatility of cross-border lending flows, it also implies that local borrowers resort more to lending from abroad. Taking advantage of the granularity of our confidential dataset, we finally explore heterogeneities and show that such leakages arise only for financially more open economies and only through the financial sector, with evidence that such leakages are driven by intra-group lending.
\end{abstract}

Keywords: Monetary Policy, Prudential Policy, Policy Interactions, Spillovers, Prudential Leakages, International Banking JEL classification: E52; F34; F36; F42; G18; G21

\footnotetext{
${ }^{1}$ Banque de France

†Baptiste Meunier: baptiste.meunier@banque-france.fr $\ddagger$ Justine Pedrono: justine.pedrono@banque-france.fr

* We are very grateful to Rhiannon Sowerbutts and Galina Hale (discussants), Julia Schmidt, Matthieu Bussiere, Dennis Reinhardt, and Simon Lloyd as well as participants of International Banking Research Network (IBRN) meetings at the BIS (August 2018), the Banque de France (Februray 2019), and the New York Fed (July 2019) for useful comments. We thank Laurence Lelogeais for excellent assistance and advice regarding the data on lending. The views expressed here are those of the authors and do not necessarily represent those of the Banque de France.
}

Working Papers reflect the opinions of the authors and do not necessarily express the views of the Banque de France. This document is available on publications.banque-france.fr/en 


\section{NON-TECHNICAL SUMMARY}

Taking advantage of an untapped and highly granular dataset, this paper focuses on interactions at international level between monetary policy in a centre economy (Euro Area) and prudential policies in the recipient countries of monetary spillovers (our sample includes 30 advanced and emerging economies). The question of interest relates to whether prudential policy in a recipient country introduces prudential leakages and can dampen the inward monetary spillovers from France. On the one hand, cross-border bank lending has been identified as a key transmission mechanism for such spillovers. In the other hand, prudential policy has been extensively used notably in emerging economies, suggesting that prudential instruments might influence monetary transmission as the two policies run through the same transmission channels.

Figure 1 depicts changes of French bank's cross-border loans conditioned by the prudential stance of the recipient country. In general, the variations in cross-border lending go in the same direction. However, the magnitude of these variations appear to be smaller for countries with tighter prudential policies - more clearly at the end of the period. Because all banks are subject to Euro Area monetary policy shocks, the heterogeneity in cross-border loans suggests that prudential policy in the recipient country can be a determinant of monetary policy spillovers. This focus on cross-border interactions is justified by the fact that : (i) given their high degree of internationalization, French banks are likely to pass on monetary shocks abroad, and (ii) foreign economies, in particular emerging markets, have made an intensive use of prudential instruments whereas there has been little variation in French prudential stance.

Our results confirm an empirical evidence of interactions: a tighter prudential stance in a recipient country limits the volatility of cross-border lending induced by unexpected monetary shocks in the Euro Area. It suggests that prudential instruments are effective in shielding the domestic lending cycle from monetary shocks abroad. However - leaving apart the interactions with monetary policy - we also shed light on prudential leakages as a prudential tightening leads to higher inward crossborder lending. This latter finding is in line with previous empirical studies which show evidence that the effect of a prudential tightening can be partially offset by domestic borrowers resorting more to loans from abroad. Taken together, these results suggest a trade-off vis-a-vis external lending: while a tighter prudential stance limits its volatility on the one hand, it encourages borrowers to resort more on it on the other hand.

Finally, drawing on the granularity of our dataset, we explore heterogeneities both at the country and at the bank level. We find that prudential leakages are significant only for the more financially open countries. We also show that leakages do not occur directly through cross-border lending to final consumers (non-financial firms and households) but indirectly through financial institutions in the destination country. Finally, we provide evidence that such leakages are driven by intra-group lending, meaning that French banks transfer funds to their local branches network. This may be motivated by the intention to gain market share over national banks that are subject to regulation. 
Figure 1: French cross-border loans.

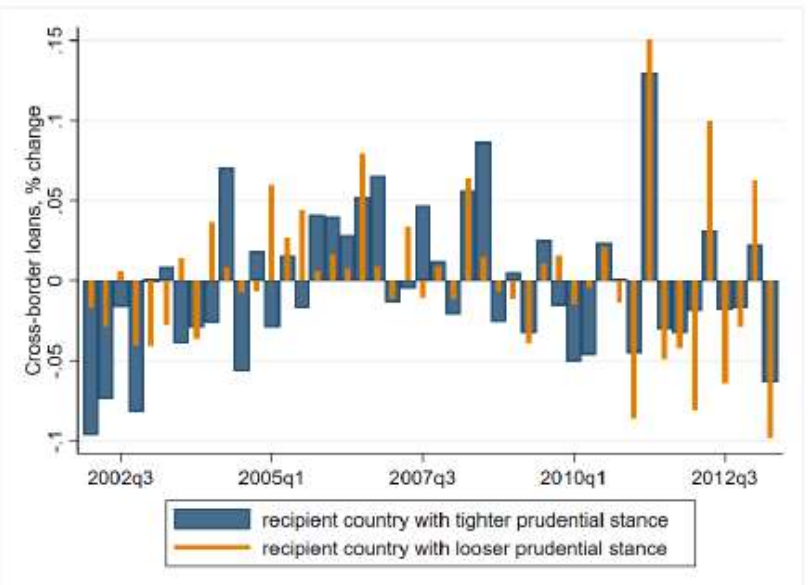

This graph shows the average quarterly change of French banks' cross-border loans conditioned by the prudential stance of the rrapient country. A tighter (leoser) pradential stance implies that the cumulative of alt prodential actions in the recipient conntry has increased (decreased) over the fast two years. This figure focuses on countries with either a tighterning or a loosening of their prudential stance. Source: Bank of France, Cerutti et at. (2017b).

\title{
Un arbitrage prudentiel? Fuites et interactions avec la politique monétaire
}

\author{
RÉSUMÉ
}

\begin{abstract}
Alors que les politiques monétaires et prudentielles sont généralement analysées séparément, ce document étudie les interactions entre les deux. Nous nous plaçons dans une perspective internationale et montrons que la politique monétaire d'une économie «centrale» (la zone euro, ZE) introduit des spillovers transfrontaliers via le crédit bancaire - ce qui induit donc de la volatilité dans les flux de prêts transfrontaliers. En étudiant plus de 30 pays de destination de ces spillovers, avancés et émergent, nous trouvons empiriquement que la politique prudentielle dans le pays de destination interagit avec la politique monétaire de la ZE de telle manière qu'une politique prudentielle plus stricte atténue la volatilité des flux de prêts transfrontaliers induite par la politique monétaire de la ZE. Toutefois, interactions à part, nous montrons également qu'une politique prudentielle plus stricte implique aussi une croissance plus forte des prêts transfrontaliers. Pris ensemble, ces résultats pourraient suggérer un arbitrage dans les pays de destination: si une politique prudentielle plus stricte réduit la volatilité des flux de prêts transfrontaliers induite par les spillovers monétaires, elle implique également que les emprunteurs locaux auront davantage recours aux prêts venant de l'étranger. En tirant parti de la granularité de nos données, nous explorons enfin les hétérogénéités et montrons que de telles « fuites » prudentielles ne se produisent que pour les économies financièrement les plus ouvertes et uniquement par le biais du secteur financier - nos résultats suggérant en outre que cela passe principalement par les prêts intragroupes.
\end{abstract}

Mots-clés : Politique Monétaire, Politique Prudentielle, Interactions, Banques Internationales

Les Documents de travail reflètent les idées personnelles de leurs auteurs et n'expriment pas nécessairement la position de la Banque de France. Ils sont disponibles sur publications.banque-france.fr 


\section{Introduction}

With increasing financial integration and massive monetary support in the aftermath of the Great Financial Crisis (GFC) and the Great Lockdown, the issue of monetary spillovers has become more acute - with a special attention to the role of spillovers from "centre" economies in shaping the global cycle (Gerko and Rey (2017)). Crossborder bank lending - the focus of our paper - has been identified as a key transmission mechanism for such spillovers, in particular in a recent cross-country effort by Buch et al. (2019). In the meantime, prudential policy has been extensively used notably in emerging economies. Intuition dictates that prudential instruments might influence monetary transmission as the two policies run through the same transmission channels. For example, the risk-taking channel is not only a key lever for unconventional monetary policy but also the main focus for regulatory instruments such as sectoral capital buffers or loan-to-value ratios ${ }^{1}$ (Adrian and Shin (2008)). Theoretical models such as Aghion and Kharroubi (2013) support this intuition and include such interactions. Policy-wise, the debate remains vivid among policy makers on the interplay - substitutability vs. complementarity - between the two policies (e.g. Yellen (2010) and Praet (2018)).

Taking advantage of an untapped and highly granular dataset, this paper focuses on interactions at international level between monetary policy in a centre economy (Euro Area) and prudential policies in the recipient countries of monetary spillovers (our sample includes 30 advanced and emerging economies). The question of interest relates to whether prudential policy in a recipient country can dampen the inward monetary spillovers from France. While this focus on cross-border interactions is little known in the literature ${ }^{2}$, it is justified by the facts that: (i) given their high degree of internationalization, French banks are likely to pass on monetary shocks abroad, and (ii) foreign economies, in particular emerging markets, have made an intensive use of prudential instruments whereas there has been little variation in French prudential stance.

Figure 1 depicts changes of French bank's cross-border loans conditioned by the prudential stance of the recipient country. In general, the variations in cross-border lending go in the same direction. However, the magnitude of these variations appear to be smaller for countries with tighter prudential policies - more clearly at the end of the period. Because all banks are subject to Euro Area monetary policy shocks, the heterogeneity in cross-border loans suggests that prudential policy in the recipient country can be a determinant of monetary policy spillovers.

Our results confirm the empirical evidence of interactions detailed in Bussiere et al.

\footnotetext{
${ }^{1}$ The argument stands as well for other channels: monetary transmission through real estate prices and stock valuations is affected by instruments such as capital requirements. Basic monetary transmission through an increase of the monetary base is also impacted by higher reserve requirements.

${ }^{2}$ The empirical literature on interactions between monetary and prudential policies is scarce and explores mainly interactions at the domestic level - with the notable exception of the recent IBRN initiative summarised in Bussiere et al. (2021a). See section 2 for a comprehensive literature review.
} 
Figure 1: French cross-border loans.

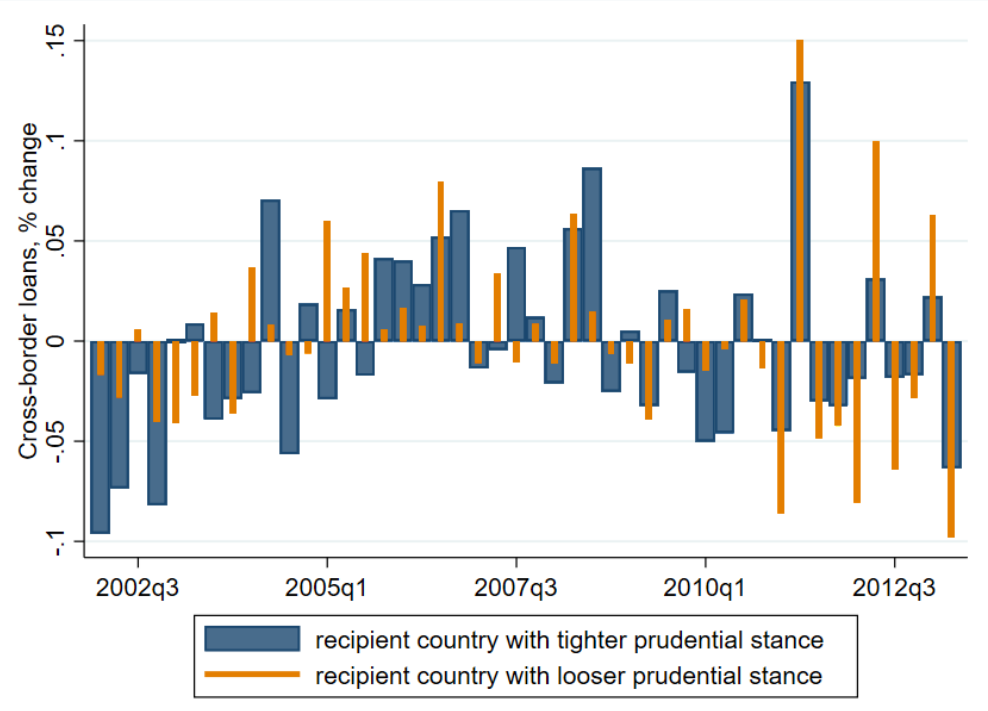

This graph shows the average quarterly change of French banks' cross-border loans conditioned by the prudential stance of the recipient country. A tighter (looser) prudential stance implies that the cumulative of all prudential actions in the recipient country has increased (decreased) over the last two years. This figure focuses on countries with either a tightening or a loosening of their prudential stance. Source: Bank of France, Cerutti et al. (2017b).

(2021a). In particular, a tighter prudential stance in a recipient country limits the volatility of cross-border lending induced by unexpected monetary shocks in the Euro Area. It suggests that prudential instruments are effective in shielding the domestic lending cycle from monetary shocks abroad. However - leaving apart the interactions with monetary policy - we also shed light on prudential leakages as a prudential tightening leads to higher inward cross-border lending. This latter finding is in line with empirical studies such as Aiyar et al. (2014b) and Reinhardt and Sowerbutts (2015) for whom the effect of a prudential tightening can be partially offset by domestic borrowers resorting more to loans from abroad. Finally, drawing on the granularity of our dataset, we explore heterogeneities. We find that prudential leakages are significant only for the more financially open economies - in line with Cerutti et al. (2017a). We also show that leakages do not occur directly through cross-border lending to final consumers (non-financial firms and households) but indirectly through financial institutions in the destination country. Finally, we provide new evidence that such leakages are driven by intra-group lending, meaning that French banks transfer funds to their local branches network. This may be motivated by the intention to gain market share over national banks that are subject to regulation ${ }^{3}$. Taken together, these results suggest a new trade-

\footnotetext{
${ }^{3} \mathrm{An}$ avenue for future research would be disentangle more formally intra-group vs. extra-group financial lending but our dataset does not allow for it. Looking at the perspective of a recipient-country - as to whether a prudential tightening translates into higher market share for foreign banks - would also be valuable.
} 
off vis-a-vis external lending: while a tighter prudential stance limits its volatility on the one hand, it encourages borrowers to resort on it on the other hand.

Despite the centrality of the policy question, empirical literature on interactions between monetary and prudential policies have however remained limited - and almost never addresses cross-border interactions. This paper contributes to the literature by filling the gap and complements the recent cross-country effort summarised in Bussiere et al. (2021a). But unlike this latter initiative, another contribution from this paper relates to the literature on prudential leakages: not only we find new empirical evidence for such leakages, but we also explore the heterogeneity across levels of financial development in the destination-country, counterpart sectors, and banks. A third contribution of this paper is to combine prudential interactions and leakages in the same framework in order to identify a prudential trade-off. To the best of our knowledge, this is the first empirical paper to explore both in a single paper.

This paper is divided as follows: section 2 gives an outlook of the related literature, section 3 details data, section 4 the empirical specification, and section 5 presents the results. Section 6 concludes.

\section{Literature review}

This paper first relates to the literature on international monetary policy transmission and closely pertains to literature focusing on the international transmission of monetary policy through the bank-lending channel (e.g Bruno and Shin (2015a) or Schmidt et al. (2018)). Most notably, Buch et al. (2019) have examined monetary spillovers from centre economies (EA, US, UK and Japan). Their key finding is that monetary policy has pervasive cross-border spillover effects via bank lending both in conventional and unconventional monetary policy periods. Our paper contributes by highlighting the role of prudential policies in partially offsetting such monetary spillovers.

This paper is also related to the literature on prudential policy. Our results brings new empirical evidence on how cross-border leakages might undermine the effect of domestic prudential policy. Aiyar et al. (2014b) and Reinhardt and Sowerbutts (2015) have explored leakages that arise when a prudential instrument affects domestic banks but not the local branches of foreign banks. They find evidence that unregulated (foreign) banks increase their lending in response to tighter capital requirements; and they estimate that this substitution can amount to about one-third of the initial effect from the regulatory change. Bussiere et al. (2017) find similar result on the French case but they focus on the inward transmission while we address outward spillovers. Some studies points also out to heterogeneities regarding recipient countries, such as Cerutti et al. (2017a) who suggest stronger leakages in the financially more open economies. On top of this empirical literature, prudential leakages have had a recent extension in the 
theoretical field with Rubio (2020) introducing them in a DSGE model.

A strand of the literature also explore interactions between monetary and prudential policies. A number of theoretical papers have incorporated them in models and generally conclude that tighter regulations reduce the transmission of monetary policy. For example, Aghion and Kharroubi (2013) model the interplay between those policies at domestic level and find that stricter regulations constraint loan supply as banks will require higher collateral, therefore weakening the responsiveness of credit to policy rate. In a DSGE model, Darracq-Paries et al. (2019) find that countercyclical prudential interventions are supportive of monetary policy conduct through the cycle. Using a broader range of macroeconomic models, Darracq-Paries et al. (2020) quantify how monetary and prudential policies can dampen their respective macroeconomic effect in a monetary union. In an international set-up closer to our approach, Unsal (2013) concludes that tighter prudential policy at home can soften the impact of foreign monetary shocks on the domestic credit cycle. In the same vein, Cao and Dinger (2018) - extending Bruno and Shin (2015b) - show that in small open economies the prudential policy helps in containing credit booms which might originate from a monetary loosening abroad.

The empirical literature on such interactions remains however scarce and, in contrast with our approach, most of it has focused on interactions at domestic level. For example, Forbes et al. (2017) and de Jonghe et al. (2020) find evidence of interactions between capital requirements and monetary policy respectively in the UK and in Belgium. For Latin America, Gambacorta and Murcia (2019) find similar interactions at the domestic level and show that the effect of prudential policy on credit growth is amplified when monetary policy pulls in the same direction. In addition, a number of papers have explored heterogeneities in those interactions. de Marco and Wieladek (2016) demonstrate the presence of interactions only for small banks. Aiyar et al. (2014a) explore heterogeneities regarding the counterpart sector and find that banks would tend to cut back credit to other banks more than to firms and households, consistent with shorter maturity, wholesale lending which is easier to roll off.

Our paper is more closely related to the few papers that have been interested in interactions between monetary policy in one place and prudential policy in another. Using BIS locational data, Bremus and Fratzscher (2015) find that expansionary monetary policies drives cross-border banking outflows and show that these flows can be mitigated by tighter regulation in recipient countries - but they focus on syndicated loans. More specifically, Andra and Lloyd (2019) find that prudential policies in emerging markets can offset the spillover effects of US monetary policy. Breaking down cross-border loans by their currency denomination, Takats and Temesvary (2019) and Takats and Temesvary (2020) find evidence that tighter macro-prudential policy in a destination-country mitigates the impact of monetary policy on cross-border loans - but they however focus on monetary policy in currency issuers and their effect on all loans denominated in this currency notwithstanding their origin. Closest to us are Bussiere et al. (2021b) who also empirically explore interactions for EA monetary policy - but focus specifically on 
its transmission and interactions with prudential policies abroad through international financial centres. In line with papers detailed in Bussiere et al. (2021a), our paper studies the interactions between monetary and prudential policy at an international level; however, our paper combines both interactions and prudential leakages in order identify a prudential trade-off.

\section{Data}

Our analysis is based on an untapped and confidential dataset compiled by the French supervisor (Autorité de Contrôle Prudentiel et de Résolution) which includes crossborder loans for all banking branches located in France. It covers cross-border loans disaggregated by bank and by country, allowing to control for banks' and countries' characteristics. To allow for more granularity, data is taken at the unconsolidated bank level $^{4}$. We restrict the sample to French-owned banks with sufficiently large international presence $^{5}$. Finally, from an initial sample of more than 500 banks, only 31 are retained.

The dependent variable $\Delta Y_{b, j, t}$ is the quarterly log change for exchange-rate adjusted cross-border lending of a bank $b$ to the country $j$. Where relevant, the dependent variable can be disaggregated by counterpart sector $s$ (financial vs. non-financial sectors). Observations are truncated if the quarterly growth rate exceeds $+100 /-100 \%$ which notably alleviates issues pertaining to mergers and acquisitions. Continuity is imposed by restricting to observations that are part of a group of at least eight consecutive quarters of non-missing observations. Our sample runs from 2000 Q1 to 2013 Q2.

Prudential data comes from the 2019 update of Cerutti et al. (2017b). It includes seven types of macro- and micro-prudential instruments: capital requirements, sectorspecific capital buffers, loan-to-value ratios, reserve requirements (both for foreign- and local-currency deposits), interbank exposure limits, and concentration ratios. In the database, regulatory tightening are coded as +1 and conversely a loosening is associated with -1 . For reserve requirements and sector-specific capital buffers, figures can be larger than 1 on absolute values to capture the intensity of the change. On top of including many instruments, this dataset also has the double advantage of wide coverage (64 countries) and extensive timespan (2000-2017).

Our prudential index is the cumulation of all prudential actions taken over the 2 years prior to $t$. This allows to take into account the persistence and the transmission lags

\footnotetext{
${ }^{4}$ This choice is also made to increase the number of observations to a sufficient level. When taking consolidated data, several problems arise: the high concentration of the French banking system with around $85 \%$ of the domestic credit market carried out by nine banking groups; the presence of numerous mergers and acquisitions; and the fact that consolidated data are only available at biannual frequency.

${ }^{5}$ bank observations with loans to non-banks smaller than EUR 100 million, or total assets smaller than EUR 1 billion, are excluded; banks for which foreign assets represent less than $0.5 \%$ of total assets are also excluded; and only banks with a positive stock of loans in at least five countries are kept
} 
of prudential policy ${ }^{6}$. We check the robustness of our specification by also considering longer periods of cumulation (3 years, 5 years, and since start). However cumulating over a too long period leads to the risk that policy reversals suppress any variation. We exclude reserve requirements since some emerging countries have been using these instruments as an alternative for monetary policy (Claessens et al. (2013)).

The prime concern with the monetary policy variable is that it should be exogenous with respect to the dependent variable. Among all monetary policy indexes considered in the literature - excess reserves, (shadow) policy rates, deviations from a Taylor rule, or monetary surprises - the latter seems the more likely to be orthogonal to changes in bank lending growth. It indeed alleviates the potential endogeneity issue that monetary policy may depend on cross-border lending or that both could be driven by omitted third factors. Data on monetary policy surprises is taken from Andrade and Ferroni (2019). Monetary surprises are extracted from market-based expectations of interest rates in short periods surrounding ECB policy announcements and press conferences. It captures the "surprise" component of policy: futures at the start of time window reflects anticipated monetary policy prior to the ECB announcement and the only substantive macroeconomic news within the time window pertains to monetary policy announcements.

\section{Empirical framework}

Our baseline specification explores the effects of interactions between ECB monetary policy and prudential stance in the destination-country on the growth rate of crossborder lending from France to the destination-country:

$$
\begin{aligned}
\Delta Y_{b, j, t}=\alpha_{0}+\sum_{k=0}^{K} \alpha_{1, k} M P_{t-k}^{\text {home }} & +\alpha_{2} \operatorname{Pru}_{j, t-K-1}^{\text {destination }}+\sum_{k=0}^{K} \alpha_{3, k} M P_{t-k}^{\text {home }} \times \operatorname{Pru}_{j, t-K-1}^{\text {destination }} \\
+ & \alpha_{4} X_{b, t-1}+\alpha_{5} Z_{j, t-1}+\alpha_{6} W_{t-3 ; t}+f_{b}+f_{j}+\epsilon_{b, j, t}
\end{aligned}
$$

$\Delta Y_{b, j, t}$ represents quarterly change in cross-border loans from the bank $b$ located in France towards the country $j$ at date $t . M P_{t-k}^{\text {home }}$ accounts for ECB monetary policy surprise at date $t-k$. In our baseline framework, $K=3$ which reflects the idea that monetary policy shocks can take up to a one-year to fully transmit - a common specification within the literature (see ECB (2010)). $P r u_{j, t-K-1}^{\text {destination }}$ is the prudential stance in destination country. It's worth noting that, to avoid endogeneity, the stance is taken

\footnotetext{
${ }^{6}$ It might take several months between the beginning of discussions and the final implementation to set up a prudential instrument
} 
in $t-K-1$, therefore prior to any monetary policy action. $X_{b, t-1}$ is a vector of timevarying bank controls (detailed below) which have been found to have an influence on cross-border loans in the literature. $Z_{j, t-1}$ are control for the financial and the business cycles in the destination-country. $W_{t-3 ; t}$ are global controls: we include the VIX at at date $t-1$ and the US monetary policy at all dates $t-k$ with $k$ between 0 and 3 . We finally include time-invariant fixed effects for banks $\left(f_{b}\right)$ and destination-country $\left(f_{j}\right)$. Standard errors are clustered at the bank-time level.

More specifically, time-varying bank-specific balance sheet characteristics included in our specification:

- Total assets deflated by the GDP deflator LogTotalAssets ${ }_{t-1}$ which accounts for the size of the bank, which can imply preferential access to external funding due to "too big to fail" status.

- Share of Tier 1 capital over total assets Tier 1 Ratio $_{t-1}$ which accounts for the capital "quality" of the financial institution, since the adjustment of loans in response to monetary shocks could be impaired by capital constraints.

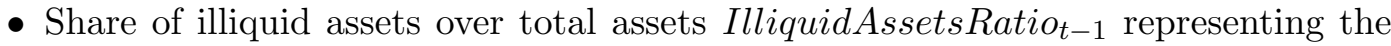
ability of a bank to adjust its asset side to policy changes. Following Kashyap and Stein (2000), monetary policy might have a greater impact on banks with lower buffers of liquid assets.

- Share of bank's foreign assets over total assets InternationalActivityt-1 which measures the degree of internationalization of the bank.

- Share of bank's net intragroup funding NetIntragroupFunding t-1 $_{t}$ i.e. liabilities of the bank vis-a-visits branches abroad minus the corresponding assets, scaled by total assets. Internal liquidity management matter for international banks as shown in Cetorelli and Goldberg (2012) who find evidence that banks which managed liquidity on a global scale used it to shield their operations from monetary shocks.

- Share of core deposits over total assets CoreDepositsRatiot-1 since a bank with a high ratio can build on a more stable and more reliant funding source. This control captures the extent to which banks have an ex ante access to alternative sources of funding. In the literature, Buch and Goldberg (2017) show that the ratio of deposit funding can differentiate the response of cross-border lending.

- Percentage of unused commitments over assets CommitmentRatio t-1 $_{-1}$ since a substantial amount of loans is made under commitments.

In addition, we also run regressions including time fixed effects to focus specifically on interactions and prudential policy in the recipient-country. While adding such fixed 
effects takes out the identification of monetary policy, it allows for a clearer identification of country-specific variables - i.e. prudential policy alone and its interaction with EA monetary policy - as it controls for any global development that would affect all destination countries.

$$
\begin{aligned}
& \Delta Y_{b, j, t}=\alpha_{0}+\alpha_{2} \operatorname{Pr} u_{j, t-K-1}^{\text {destination }}+\sum_{k=0}^{K} \alpha_{3, k} M P_{t-k}^{\text {home }} \times \operatorname{Pr} u_{j, t-K-1}^{\text {destination }} \\
& +\alpha_{4} X_{b, t-1}+\alpha_{5} Z_{j, t-1}+f_{b}+f_{j}+f_{t}+\epsilon_{b, j, t}
\end{aligned}
$$

\section{$5 \quad$ Results}

\subsection{Baseline regression}

We first observe the separate impacts of monetary and prudential policies on crossborder lending by running the baseline regression without interaction terms. Results are reported in the column 1 of table 1 . As expected, monetary policy enters with a significant and negative sign: a monetary loosening drives outflows from France towards the rest of the world.

We then interact prudential policy in the destination-country and EA monetary policy surprises. Results are reported in column 2. For monetary policy and interactions from t-1 to t-3, we summarize the total impact by summing individual coefficients up to $\mathrm{t}-\mathrm{K}$ and evaluating their joint significance through a F-test. A key result is that the prudential stance enters with a positive sign. This indicates that a prudential tightening in destination-country exerts a positive effect on cross-border lending from France. Such evidence for "leakage" of prudential policies is in line with a number of empirical papers such as Aiyar et al. (2014b) and Reinhardt and Sowerbutts (2015) for the UK or Bussiere et al. (2017) in the French case.

Interactions are significant and positive: the more regulated a destination-country, the less volatile cross-border lending flows are in response to an unexpected monetary shocks from the ECB. This result indicates that destination-countries have the ability to shield, to a certain extent, their domestic lending cycle against external shocks. This result is in line with Bremus and Fratzscher (2015), Andra and Lloyd (2019), and Bussiere et al. (2021b) for whom tighter regulation at home would limit the volatility of inward cross-border lending flows induced by a monetary shock abroad.

Both results are confirmed in column 3 which includes time fixed effects. Taken together, they suggest an ambiguous role of prudential policy with respect to cross- 
border lending. A tighter prudential stance means that leakages arise - likely as local borrowers resort more to lending from abroad to make up for more constrained banking conditions at home. On the other hand, as prudential policy at home interacts with monetary policy abroad, it means that a tighter prudential stance dampens the volatility of cross-border lending flows from abroad. To summarize: a tighter prudential stance means more lending from abroad but in a less volatile fashion.

Regarding control variables, we find evidence that balance sheet characteristics and destination-country controls do matter for cross-border lending: lower capital ratio and higher dependence on intragroup funding are associated with greater cross-border loans. This is consistent with the literature finding that when banks rely more on internal capital market, financial flows from the parent country to branches abroad will be larger (e.g. Cetorelli and Goldberg (2012)). Finally, results show the significance of destination-country controls, suggesting that banks' decision to engage in cross-border lending are primarily driven by local economic conditions in the destination-country. That way, banks tends to have a procyclical behaviour, with bank lending peaking when cycles are well oriented - in line with the findings of Asea and Blomberg (1998).

Finally, we also run some robustness checks regarding the calibration of monetary and prudential variables. ${ }^{7}$ We run regressions with different cumulations for the prudential index (respectively for 3 years, 5 years, and and since start). The coefficient on the prudential stance remains positive and significant up to 5 years and interaction terms are found significant across all cumulations. This confirms the robustness of our findings, and indicates that long-standing regulatory policies tend to have less and less influence. We also run regressions with only one lag of monetary policy and find that the coefficient of monetary policy becomes insignificant. This indicates that a 6 -month period is not sufficient for monetary policy to deliver its full impact - in line with literature concluding that monetary policy takes around 12 months to unfold entirely (e.g. ECB (2010)).

\footnotetext{
${ }^{7}$ Details on robustness checks are available upon request.
} 
Table 1: Baseline regression results

\begin{tabular}{|c|c|c|c|}
\hline & $\begin{array}{c}(1) \\
\text { Without } \\
\text { interactions }\end{array}$ & $\begin{array}{c}(2) \\
\text { Baseline } \\
\text { regression }\end{array}$ & $\begin{array}{c}\text { (3) } \\
\text { Time } \\
\text { fixed effects }\end{array}$ \\
\hline EA monetary policy $(\mathrm{MP})_{t}$ & $\begin{array}{c}0.027 \\
{[0.817]}\end{array}$ & $\begin{array}{c}0.009 \\
{[0.939]}\end{array}$ & \\
\hline Sum of EA MP $\mathrm{MP}_{t-1}$ & $\begin{array}{l}-0.074 \\
{[0.680]}\end{array}$ & $\begin{array}{l}-0.138 \\
{[0.445]}\end{array}$ & \\
\hline Sum of EA MP $\mathrm{MP}_{t-2}$ & $\begin{array}{l}-0.302 \\
{[0.128]}\end{array}$ & $\begin{array}{c}-0.390^{*} \\
{[0.054]}\end{array}$ & \\
\hline Sum of EA MP ${ }_{t-3}$ & $\begin{array}{l}-0.315 \\
{[0.217]}\end{array}$ & $\begin{array}{c}-0.427^{*} \\
{[0.097]}\end{array}$ & \\
\hline Prudential stance $t-4$ & $\begin{array}{c}0.003 \\
{[0.234]}\end{array}$ & $\begin{array}{l}0.005^{*} \\
{[0.087]}\end{array}$ & $\begin{array}{l}0.005^{*} \\
{[0.090]}\end{array}$ \\
\hline Interaction term $_{t}$ & & $\begin{array}{c}0.094 \\
{[0.277]}\end{array}$ & $\begin{array}{c}0.057 \\
{[0.514]}\end{array}$ \\
\hline Sum of interactions $s_{t-1}$ & & $\begin{array}{c}0.262^{* *} \\
{[0.034]}\end{array}$ & $\begin{array}{l}0.213^{*} \\
{[0.092]}\end{array}$ \\
\hline Sum of interactions $s_{t-2}$ & & $\begin{array}{c}0.340^{* *} \\
{[0.016]}\end{array}$ & $\begin{array}{c}0.288^{* *} \\
{[0.043]}\end{array}$ \\
\hline Sum of interactions $t-3$ & & $\begin{array}{c}0.421^{* *} \\
{[0.010]}\end{array}$ & $\begin{array}{c}0.335^{* *} \\
{[0.043]}\end{array}$ \\
\hline Log Total Assets $_{t-1}$ & $\begin{array}{l}-0.024 \\
{[0.236]}\end{array}$ & $\begin{array}{l}-0.025 \\
{[0.194]}\end{array}$ & $\begin{array}{l}-0.047 \\
{[0.194]}\end{array}$ \\
\hline Tier1 Ratio $_{t-1}$ & $\begin{array}{c}-0.006^{* *} \\
{[0.032]}\end{array}$ & $\begin{array}{c}-0.006^{* *} \\
{[0.030]}\end{array}$ & $\begin{array}{c}-0.006^{* *} \\
{[0.049]}\end{array}$ \\
\hline Illiquid Assets Ratiot-1 & $\begin{array}{l}0.001^{*} \\
{[0.074]}\end{array}$ & $\begin{array}{l}0.001^{*} \\
{[0.076]}\end{array}$ & $\begin{array}{c}0.001 \\
{[0.123]}\end{array}$ \\
\hline International Activity $_{t-1}$ & $\begin{array}{l}0.002^{*} \\
{[0.091]}\end{array}$ & $\begin{array}{l}0.002^{*} \\
{[0.086]}\end{array}$ & $\begin{array}{l}0.003^{*} \\
{[0.089]}\end{array}$ \\
\hline Net Intragroup Funding ${ }_{t-1}$ & $\begin{array}{c}0.004^{* * *} \\
{[0.000]}\end{array}$ & $\begin{array}{c}0.004^{* * *} \\
{[0.000]}\end{array}$ & $\begin{array}{c}0.004^{* * *} \\
{[0.006]}\end{array}$ \\
\hline Core Deposits Ratio $t-1$ & $\begin{array}{c}0.001 \\
{[0.266]}\end{array}$ & $\begin{array}{c}0.001 \\
{[0.249]}\end{array}$ & $\begin{array}{c}0.001 \\
{[0.510]}\end{array}$ \\
\hline Commitment Ratio $t-1$ & $\begin{array}{c}0.003 \\
{[0.223]}\end{array}$ & $\begin{array}{c}0.003 \\
{[0.229]}\end{array}$ & $\begin{array}{c}0.002 \\
{[0.466]}\end{array}$ \\
\hline $\operatorname{VIX}_{t-1}$ & $\begin{array}{c}0.000 \\
{[0.573]}\end{array}$ & $\begin{array}{l}-0.000 \\
{[0.608]}\end{array}$ & \\
\hline Dest. financial cycle ${ }_{t-1}$ & $\begin{array}{c}0.017 \\
{[0.381]}\end{array}$ & $\begin{array}{c}0.017 \\
{[0.371]}\end{array}$ & $\begin{array}{c}0.012 \\
{[0.532]}\end{array}$ \\
\hline Dest. business cycle $t-1$ & $\begin{array}{c}0.677^{* * *} \\
{[0.000]}\end{array}$ & $\begin{array}{c}0.689^{* * *} \\
{[0.000]}\end{array}$ & $\begin{array}{c}0.577^{* * * *} \\
{[0.000]}\end{array}$ \\
\hline US MP & Yes & Yes & Yes \\
\hline Time fixed effects & No & No & Yes \\
\hline Observations & 11,136 & 11,136 & 11,136 \\
\hline R-squared & 0.02 & 0.02 & 0.03 \\
\hline $\begin{array}{l}\text { Adjusted R-squared } \\
\text { Number of banks }\end{array}$ & $\begin{array}{c}0.01 \\
31\end{array}$ & $\begin{array}{c}0.01 \\
31\end{array}$ & $\begin{array}{c}0.02 \\
31\end{array}$ \\
\hline $\begin{array}{l}\text { Note: Standard errors, in } \\
\text { and } * * * \text { denote statistical s } \\
\text { The coefficients for monet } \\
\text { the sum of the individual } \\
\text { the p-value of the F-test fo }\end{array}$ & $\begin{array}{l}\text { ets, are clu } \\
\text { cance below } \\
\text { olicy and i } \\
\text { ients from } \\
\text { it significan }\end{array}$ & $\begin{array}{l}\text { d by ban } \\
7,5 \% \text { anc } \\
\text { actions } \mathrm{fi} \\
\text { to t-K; }\end{array}$ & $\begin{array}{l}\text { d time. } *, * * \\
\text { respectively. } \\
\mathrm{t}-1 \text { to } \mathrm{t}-3 \text { are } \\
\text { value below is }\end{array}$ \\
\hline
\end{tabular}




\subsection{Exploring heterogeneities}

As shown in the literature, heterogeneities are crucial for prudential leakages - as well as for interactions. Taking advantage of the granularity of our dataset covering a broad range of destination countries, counterparts, and banks, we turn to exploring in more details those potential heterogeneities.

First, we build on Cerutti et al. (2017a) who find that prudential policies are less effective in financially open economies - suggesting larger leakages in those economies. We therefore break our sample between financially open and closed economies for which we follow the classification established by Lane and Milesi-Ferretti (2007). Results are reported in table 2 . Interactions are significant in both cases but prudential stance is significant (and positive) only for financially open economies, consistent with our hypothesis. In those countries, cross-border lending from abroad increases in response to a domestic regulatory tightening. This effect might be due to local borrowers being able to resort to lending from abroad in order to compensate for the regulatory tightening constraining local banks.

Table 2: Breakdown by financial openness

\begin{tabular}{c|c|c}
\hline & $\begin{array}{c}(1) \\
\text { Open } \\
\text { economies }\end{array}$ & $\begin{array}{c}\text { Closed } \\
\text { economies }\end{array}$ \\
\hline Prudential stance $_{t-4}$ & $0.012^{* *}$ & 0.000 \\
& {$[0.024]$} & {$[0.927]$} \\
Sum of interaction & \\
& $0.556^{*}$ & $0.340^{*}$ \\
& {$[0.060]$} & {$[0.090]$} \\
\hline Observations $_{\text {Bank controls }}$ & 5,477 & 5,659 \\
Yest. country controls & Yes & Yes \\
Time fixed effects & Yes & Yes \\
R-squared & 0.02 & 0.04 \\
Adjusted R-squared & 0.01 & 0.02 \\
Number of banks & 31 & 29 \\
\hline
\end{tabular}

We then explore heterogeneities regarding counterpart sectors following Aiyar et al. (2014a) who find that banks adjust their lending to other banks rather than to households and firms. Such decomposition would allow to characterize the underlying mechanism. As suggested above, leakages translate a sort of substitution effect by local borrowers who rely more on funding from abroad to make up for constrained local banks. Two broad mechanisms could be at play regarding this substitution:

1. Direct substitution in which banks located in France lend directly to final borrowers (non-financial corporations, households) in the destination-country. 
2. Indirect substitution in which French banks get access to final borrowers through the financial sector in place in the destination-country.

To test these mechanisms, the sample is separated across counterpart sectors - financial vs. non-financial. Results are reported in table 3. The coefficient for prudential stance is only significant for lending towards the financial sector. This suggests that the substitution happens mostly through the indirect channel as French banks are conveying funds to local banks. Results also indicate that interactions are only significant for the non-financial sector (households and firms). In other words, our results suggest that French banks have the ability to take advantage, through the financial sector, of the prudential environment in the destination country. This may be motivated by the intention to gain market share over domestic banks that are subject to regulation. In that case, prudential stance is neutral regarding monetary spillovers to the financial sector. It is interesting to note, however, that a prudential tightening leads to a greater resilience of the real economy (i.e. the non-financial sector) in response to monetary spillovers. Therefore, the prudential arbitrage highlighted at the "macro" level in fact affects differently the counterpart sectors: depending on the objectives of the financial stability authorities and the issues at stake, prudential policy must be viewed from different angles.

Table 3: Breakdown by counterparts

\begin{tabular}{c|cc}
\hline & $\begin{array}{c}(1) \\
\text { Loans to } \\
\text { non-financial } \\
\text { sector }\end{array}$ & $\begin{array}{c}\text { Loans to } \\
\text { financial } \\
\text { sector }\end{array}$ \\
\hline Prudential stance $t-4$ & 0.003 & $0.010^{*}$ \\
Sum of interaction $t-3$ & {$[0.002]$} & {$[0.005]$} \\
& $0.406^{* * *}$ & 0.170 \\
{$[0.002]$} & {$[0.555]$} \\
\hline Observations $_{\text {Bank controls }}$ & 18240 & 7160 \\
Dest. country controls & Yes & Yes \\
R-squared & 0.02 & Yes \\
Adjusted R-squared & 0.02 & 0.02 \\
Number of banks & 29 & 0.01 \\
\hline
\end{tabular}

When exploring this indirect substitution effect, a question is whether this occurs through intra-group (i.e. funds are channelled to affiliates of the same banking group) or extra-group lending. To explore this mechanism, we decompose banks along their net intragroup funding position (measured as liabilities vis-a-vis its branches abroad minus the corresponding assets) averaged over the sample period. If leakages happen through intra-group lending, the coefficient on the prudential stance should be significant only for banks with negative intragroup funding - i.e. those which generally transfer more funds to their affiliates than they receive from them. On the opposite, if leakages occur 
through extra-group lending (or a combination of both intra- and extra-group lending), the prudential stance should be significant for all banks regardless of their net intragroup funding position.

Results are reported in table 4. While interactions are significant and of similar magnitude across banks with positive or negative net intragoup funding position, the coefficient for prudential stance is significant only for those with a negative net intragroup position. It suggests that leakages arise mostly - if not only - through intra-group lending as banks in France channel funds towards their local subsidiaries or affiliates ${ }^{8}$ in the destination-country - possibly in a tentative to gain market share over domestic banks impaired by tightened regulations.

Table 4: Breakdown by mean net intragroup funding position over the sample

\begin{tabular}{c|c|c|c}
\hline & $\begin{array}{c}(1) \\
\text { Negative } \\
\text { position }\end{array}$ & $\begin{array}{c}\text { Balanced } \\
\text { position }\end{array}$ & $\begin{array}{c}\text { Positive } \\
\text { position }\end{array}$ \\
\hline Prudential stance $t-4$ & $0.011^{* *}$ & 0.009 & 0.002 \\
& {$[0.026]$} & {$[0.577]$} & {$[0.565]$} \\
Sum of interaction & \\
& $0.461^{*}$ & -0.000 & $0.442^{* *}$ \\
& {$[0.063]$} & {$[1.000]$} & {$[0.042]$} \\
\hline Observations $_{\text {Bank controls }}$ & 3275 & 442 & 7419 \\
Dest. country controls & Yes & Yes & Yes \\
R-squared & 0.03 & Yes & Yes \\
Adjusted R-squared & 0.02 & 0.05 & 0.03 \\
Number of banks & 12 & 2 & 0.02 \\
\hline
\end{tabular}

Finally, we explore the heterogeneities relative to the level of international activity (measured as the ratio of foreign assets) given the a priori importance of this feature for cross-border lending and the significance of this control variable in baseline regression. We expect that banks that have a strong knowledge of international banking might have a comparative advantage in dealing with the prudential environment in the destination country - which would imply strong prudential leakages and weak interactions for those banks. On the contrary, banks with limited experience in international banking are not expected to be as operative as more international banks in coping with the prudential environment of the destination country. Results are reported in table 5. The column 1 shows that interactions are positive and significant for banks with the lowest international presence ${ }^{9}$ - in line with de Marco and Wieladek (2016) and Bussiere et al. (2021b) showing stronger interactions for smaller and less international banks.

\footnotetext{
${ }^{8}$ One should acknowledge the distinction between a local affiliate subject to local regulation and a local subsidiary subject to the regulation of their parent bank's country. One way to circumvent local regulation for French banks would be to rather transfer funds to their local subsidiaries - which remain subject to French regulation at the contrary of domestic banks or local affiliates of French banks. Our dataset however does not allow to disentangle between lending to subsidiaries or affiliates.

${ }^{9}$ Remember however that during the data cleaning phase, banks with very limited international
} 
Prudential leakages become significant only for banks in the third quartile (column 3 ), suggesting that banks with stronger international presence are the ones through which leakages occur. Regarding banks with the largest international presence, evidence of significant leakages are observed when international financial centres (IFC) are considered in column 5. ${ }^{10}$ This result is in line with the "Pont de Londres" story from Bussiere et al. (2021b), where the responses of more international banks to prudential policies abroad pass through international financial centres. More precisely, the authors show that the more international French banks react to prudential policies in a destination-country by first adjusting their cross-border lending towards international financial centres, and second, by having their affiliates in these international financial centres to adjust their lending in the final-destination-country. Our results support this theory with a focus on prudential leakages. The most international banks have a role in prudential leakage but that, unlike for banks in the third quartile - for which leakages are operated directly from the headquarter country (France) - this leakage is done through their network of affiliates located in international financial centres.

Table 5: Quartile regression by internationalization degree

\begin{tabular}{c|c|c|c|c|c}
\hline & $(1)$ & $(2)$ & $(3)$ & $(4)$ & $(5)$ \\
& 1 1st Q & 2nd Q & 3rd Q & 4th Q & $\begin{array}{c}\text { th Q } \\
\text { to IFC }\end{array}$ \\
\hline Prudential stance $_{t-4}$ & 0.007 & 0.004 & $0.015^{* *}$ & -0.004 & $0.003^{*}$ \\
& {$[0.180]$} & {$[0.424]$} & {$[0.016]$} & {$[0.509]$} & {$[0.094]$} \\
Sum of interaction & & & & \\
& $1.015^{* * *}$ & -0.014 & 0.556 & 0.051 & 0.231 \\
& {$[0.000]$} & {$[0.986]$} & {$[0.134]$} & {$[0.882]$} & {$[0.498]$} \\
\hline Observations $_{\text {Bank controls }}$ & 2593 & 2621 & 2340 & 3582 & 3582 \\
Dest. country controls & Yes & Yes & Yes & Yes & Yes \\
R-squared & 0.07 & 0.07 & 0.03 & 0.04 & 0.04 \\
Adjusted R-squared & 0.06 & 0.04 & 0.01 & 0.02 & 0.02 \\
Number of banks & 8 & 8 & 7 & 8 & 8 \\
\hline
\end{tabular}

\section{Conclusion}

Contributing to the policy debate regarding the interplay between monetary and prudential policies, this paper finds empirical evidence that the international transmission of monetary policy from a centre economy (France) is affected by the prudential stance in the destination-country. More specifically, the tighter the prudential stance in the destination-country, the less volatile are cross-border lending flows in response to a

presence were ruled out: banks for which foreign assets represent less than $0.5 \%$ of total assets were excluded, just as banks engaged in cross-border loans with less than five different countries.

${ }^{10}$ Financial centres include the UK and Hong-Kong and the prudential stance measures the prudential stance in the rest of world. 
monetary shock in France. It suggests that local prudential authorities can, to a certain extent, shield their local credit cycle from monetary shocks in centre economies.

Interactions apart, we also find empirical evidence that a tighter prudential stance implies higher cross-border lending. This provides new evidence of prudential leakages highlighted in the literature (e.g. Aiyar et al. (2014b) and Cerutti et al. (2017a)). Taken together, these results might suggest the existence of a prudential trade-off. On the one hand, prudential policy mitigates the volatility in lending flows (through the interactions with monetary policy abroad) but on the other hand it increases the reliance on external lending. Exploring heterogeneities, we first find that leakages occur only in financially open economies - consistent with borrowers in these economies more in capacity to resort on external lending. We also find that leakages occur through the financial sector while interactions occur through the non-financial sector - meaning that a tighter prudential stance induces more resilience for the non-financial lending cycle. Finally, we find evidence that such leakages arise through intra-group lending and for the more international banks, suggesting that these banks transfer funds to their branches in the destination-country in response to a prudential tightening - possibly to gain market share over domestic banks impaired by tighter regulation.

Policy-wise, this demonstrates the relevance of prudential instruments to stabilize the domestic credit cycle, more specifically to shield it from external monetary shocks. The presence of leakages however might entails a policy trade-off for financially open economies: the stabilization of the domestic credit cycle comes at the cost of a higher reliance on foreign lending.

While this paper focuses on French banks, an avenue for future research would be the generalization of its findings to other "centre" economies. This analysis could also be interestingly supplemented by looking at the perspective of recipient-countries. 


\section{References}

Adrian, T. and Shin, H. S. (2008). Financial intermediaries, financial stability and monetary policy. Federal Reserve Bank of New York Staff Reports, 364.

Aghion, P. and Kharroubi, E. (2013). Cyclical macroeconomic policy, financial regulation, and economic growth. Bank for International Settlements working paper, 434.

Aiyar, S., Calomiris, C., Hooley, J., Korniyenko, Y., and Wieladek, T. (2014a). The international transmission of bank capital requirements: Evidence from the United Kingdom. Journal of Financial Economics, 113(3):368-382.

Aiyar, S., Calomiris, C. W., and Wieladek, T. (2014b). Does macroprudential regulation leak? evidence from a UK policy experiment. Journal of Money, Credit and Banking, 46(1):181-214.

Andra, C. and Lloyd, S. (2019). In the face of spillovers: prudential policies in emerging economies. Bank of England Working Papers, 828.

Andrade, P. and Ferroni, F. (2019). Delphic and odyssean monetary policy shocks: Evidence from the euro-area. Federal Reserve Bank of Boston Working Papers, 1917.

Asea, P. and Blomberg, B. (1998). Lending cycles. Journal of Econometrics, 83(1-2):89128.

Bremus, F. and Fratzscher, M. (2015). Drivers of structural change in cross-border banking since the global financial crisis. Journal of International Money and Finance, $52(\mathrm{C}): 32-59$.

Bruno, V. and Shin, H. S. (2015a). Capital flows and the risk-taking channel of monetary policy. Journal of Monetary Economics, 71(C):119-132.

Bruno, V. and Shin, H. S. (2015b). Cross-border banking and global liquidity. Review of Economic Studies, 82(2):535-564.

Buch, C., Bussiere, M., Goldberg, L., and Hills, R. (2019). The international transmission of monetary policy. Journal of International Money and Finance, 91(C):29-48.

Buch, C. and Goldberg, L. (2017). Cross-border prudential policy spillovers: How much? how important? evidence from the international banking research network. International Journal of Central Banking, 13(2):505-558.

Bussiere, M., Cao, J., de Haan, J., Hills, R., Lloyd, S., Meunier, B., Pedrono, J., Reinhardt, D., Sinha, S., Sowerbutts, R., and Styrin, K. (2021a). The interaction between macroprudential policy and monetary policy: Overview. Review of International Economics, 29:1-19. 
Bussiere, M., Hills, R., Lloyd, S., Meunier, B., Pedrono, J., Reinhardt, D., and Sowerbutts, R. (2021b). Le pont de londres: interactions between monetary and prudential policies in cross-border lending. Review of International Economics, 29:61-86.

Bussiere, M., Schmidt, J., and Vinas, F. (2017). International banking and cross-border effects of regulation: Lessons from france. International Journal of Central Banking, 13(2):163-193.

Cao, J. and Dinger, V. (2018). Financial globalization and bank lending: The limits of domestic monetary policy? Norges Bank Working Papers, 2018/4.

Cerutti, E., Claessens, S., and Laeven, L. (2017a). The use and effectiveness of macroprudential policies: New evidence. Journal of Financial Stability, 28(C):203-224.

Cerutti, E., Correa, R., Fiorentino, E., and Segalla, E. (2017b). Changes in prudential policy instruments: A new cross-country database. International Journal of Central Banking, 13(2):477-503.

Cetorelli, N. and Goldberg, L. (2012). Banking globalization and monetary transmission. Journal of Finance, 67(5):1811-1843.

Claessens, S., Ghosh, S., and Mihet, R. (2013). Macro-prudential policies to mitigate financial system vulnerabilities. Journal of International Money and Finance, 39(C):153-185.

Darracq-Paries, M., Karadi, P., Korner, J., Kok, C., Mazelis, F., Nikolov, K., Rancoita, E., van der Ghote, A., Weber, J., and Cozzi, G. (2020). Macroprudential policy measures: macroeconomic impact and interaction with monetary policy. European Central Bank Working Paper Series, 2376.

Darracq-Paries, M., Kok, C., and Rancoita, E. (2019). Macroprudential policy in a monetary union with cross-border banking. European Central Bank Working Paper Series, 2260.

de Jonghe, O., Dewatcher, H., and Ongena, S. (2020). Bank capital (requirements) and credit supply: evidence from pillar 2 decisions. Journal of Corporate Finance, 60(C).

de Marco, F. and Wieladek, T. (2016). The real effects of capital requirements and monetary policy: Evidence from the united kingdom. CEPR discussion paper, 11265.

ECB (2010). Monetary policy transmission in the euro area, a decade after the introduction of the euro. ECB Monthly Bulletin.

Forbes, K., Reinhardt, D., and Wieladek, T. (2017). The spillovers, interactions, and (un)intended consequences of monetary and regulatory policies. Journal of Monetary Economics, 85:1-22. 
Gambacorta, L. and Murcia, A. (2019). The impact of macroprudential policies and their interaction with monetary policy: an empirical analysis using credit registry data. In BIS, editor, Are post-crisis statistical initiatives completed? Bank for International Settlments.

Gerko, E. and Rey, H. (2017). Monetary policy in the capitals of capital. Journal of the European Economic Association, 15(4):721-745.

Kashyap, A. and Stein, J. (2000). What do a million observations on banks say about the transmission of monetary policy? American Economic Review, 90(3):407-428.

Lane, P. and Milesi-Ferretti, G.-M. (2007). The external wealth of nations mark ii: Revised and extended estimates of foreign assets and liabilities, 1970-2004. Journal of International Economics, 73(2):223-250.

Praet, P. (2018). The interaction between monetary policy and macroprudential policy. speech at the Money, Macro and Finance Research Group Conference on the Resilience of the Global Financial Architecture, London.

Reinhardt, D. and Sowerbutts, R. (2015). Regulatory arbitrage in action: Evidence from banking flows and macroprudential policy. Bank of England Working Papers, 546 .

Rubio, M. (2020). Cross-country spillovers from macroprudential regulation: Reciprocity and leakage. Journal of International Money and Finance, 103(C):102-134.

Schmidt, J., Caccavaio, M., Carpinelli, L., and Marinelli, G. (2018). International spillovers of monetary policy: Evidence from france and italy. Journal of International Money and Finance, 89:50-66.

Takats, E. and Temesvary, J. (2019). How does the interaction of macroprudential and monetary policies affect cross-border bank lending? Bank for International Settlments Working Papers, 782.

Takats, E. and Temesvary, J. (2020). The currency dimension of the bank lending channel in international monetary transmission. Journal of International Economics, $125(\mathrm{C})$.

Unsal, D. F. (2013). Capital flows and financial stability: Monetary policy and macroprudential responses. International Journal of Central Banking, 9(1):233-285.

Yellen, J. (2010). Macroprudential supervision and monetary policy in the post-crisis world. speech at the Annual Meeting of the National Association for Business Economics. 